DOI 10.18551/rjoas.2019-05.15

\title{
PERFORMANCE ANALYSIS OF SHARIA EQUITY FUND IN INDONESIA
}

\author{
Ardhitorahman Hafizh* \\ School of Business, IPB University, Indonesia \\ Beik Irfan Syauqi, Firdaus Achmad \\ STEI Tazkia University, Indonesia \\ *E-mail: dhitohafizh@gmail.com
}

\begin{abstract}
The purpose of this study is to provide information about the Sharia equity fund performance with Sharpe, Treynor and Jensen-Alpha methods in Indonesia. This study is a descriptive study using a quantitative approach. The study population was Sharia equity fund in 2015 to 2018. Samples of this study were 21 mutual funds by purposive sampling method. The analysis tool in this study is the method of measuring performance based on risk adjusted return that includes Sharpe, Treynor, and Jensen-Alpha with Microsoft Excel application. During the observation period (2015-2018) there was Sharia equity fund outperform compared with markets (IHSG and ISSI). Best Sharia equity fund is HPAM Syariah Ekuitas, OSO Syariah Equity Fund, and Lautandhana Saham Syariah.
\end{abstract}

\section{KEY WORDS}

Performance, Sharia equity fund, Sharpe, Treynor, Jensen-Alpha.

Presence of Sharia mutual funds can be one alternative investing for the majority of Indonesia's Muslim community to participate in the activities of the capital markets in a way that is lawful. But in reality, the public still doubt over the return to be received from the Fund for Sharia is not great compared to conventional mutual funds. These doubts arise because there is an allegation of suboptimal investment portfolio allocation due to the screening process which limits the investment portfolio only on products that comply with Islamic jurisprudence, whereas in Indonesia investment products Sharia is still limited in number. The performance of the portfolio reflected not only on the rate of return (return) but also on the level of risk (risk). The bigger the return obtained is increasingly higher potential losses

In the year 2013 to 2017, Sharia Funds are having a pretty good development marked by the growing number of Sharia mutual fund assets as well as a white garment. Where the value of the growth of Sharia mutual fund NAV for 5 years reached $200 \%$ from 9,432 billion Rupiah grew to be 28,311 billion Rupiah. The Islamic finance industry in Indonesia has a huge potential for growth because of the limited market share of the Islamic finance industry in Indonesia compared to conventional financial industry.

Table 1 - The development of Syariah mutual funds based on portfolio assets

\begin{tabular}{|c|c|c|}
\hline No. & Type of Mutual Fund & NAV Sharia mutual fund (Trillion Rupiah) \\
\hline 1. & Money Market & 2,05 \\
\hline 2. & Equity & 16,43 \\
\hline 3. & Fix income & 4,61 \\
\hline 4. & Mixture & 2,44 \\
\hline
\end{tabular}

Source: www.ojk.go.id.

The table above shows the phenomenon among the types of mutual funds that exist in their asset allocation, Stock equity Funds are superior to other types of mutual funds with the highest NAV value of 16,43 trillion Rupiah for Sharia Equity Funds. In general, investors will choose to invest their funds with financial considerations, namely considering returns and risks. 
From picture 1 it can be seen even though the performance of the index Sharia equity fund in early 2014 has a performance above Indonesia Sharia stock index and Jakarta composite index but in 2015 to 2017 thus progressively decreased until its performance under the return of market. In theory it should have equity fund performance over the market, but in fact the return shown by Sharia equity fund during the period $2014-2017$ could not offset the return of ISSI and $\mathrm{JCl}$. This is an indication that along with the rapid growth of Shariah-compliant mutual fund instruments, but not demonstrated by the performance of Sharia equity fund is a good therefore problems faced by investors or potential investors is how to choose an alternative to existing mutual fund based on the performance of the portfolio. Addressing these problems is important then conducted a research on the analysis of the performance of Sharia equity fund to help investors in collecting information and compare the performance of each Mutual Fund. The existence of this research are expected to stock investors have valid information to choose a Sharia equity fund that could potentially generate a profit optimal.

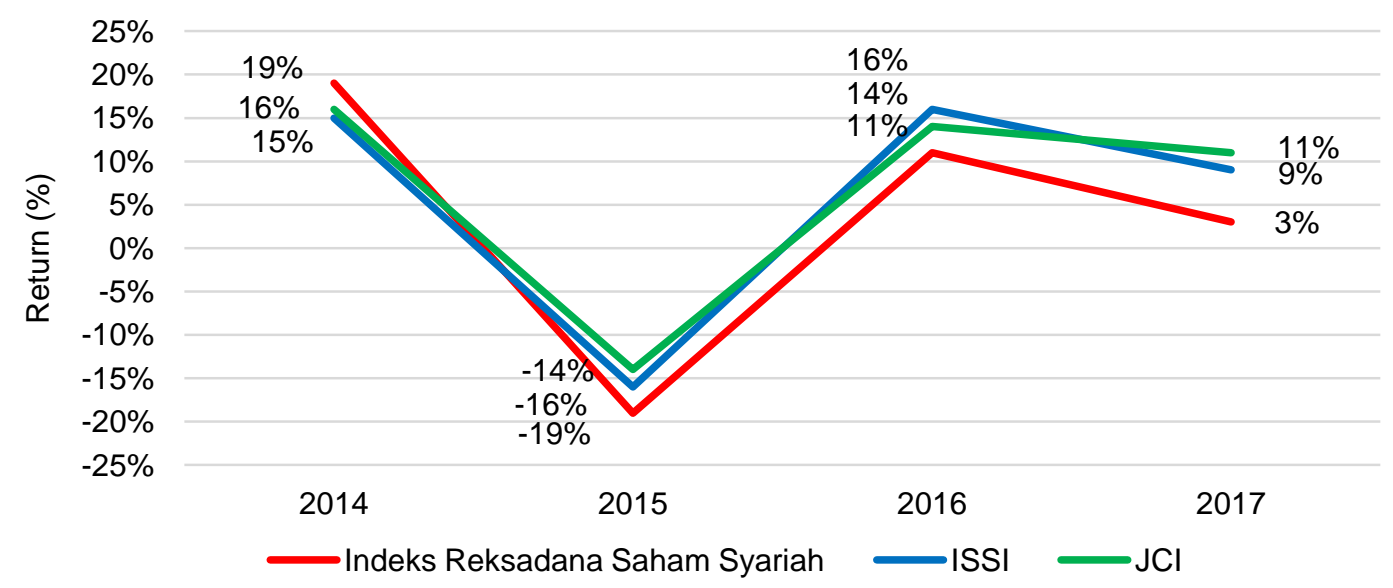

Figure 1 - Comparison of returns between the Sharia equity fund index, Indonesian Sharia stock index and Jakarta composite index

Based on the explanation above, the research question for this study is: "How is the performance of Sharia equity funds based on methods Sharpe, Treynor, and Jensen-Alpha on market performance ISSI and JCI from 2015 to 2018.

This research aims to analyze the performance of Sharia equity funds based on methods Sharpe, Treynor, and Jensen-Alpha with market performance ISSI and JCI from 2015 to 2018.

\section{LITERATURE REVIEW}

Investment is the amount of the current commitment during a certain period to generate a rate of return in the future as compensation the top investor: the time it takes for the commitment of funds, inflation rate, and the uncertainty of returns funds in the future (Zaenal, 2007). Mutual funds are a container and service provision established to help investors who want to participate in the capital market without direct involvement in procedures, administration, and analysis in a capital market. This is due to the mutual funds managed by investment managers who represent investors who participate in mutual funds, therefore it is reasonable when the performance of mutual funds managed by professional investment managers can exceed the performance of the portofolio is composed of ordinary investors who only buy and hold strategies (Abdul, 2010).

In General, investors will choose to invest their funds with financial considerations, i.e. considering the yield (return) and risks (risk) merely. Investors need a method of measurement as a tool that can help to determine the portfolio of the mutual fund of his choice, so should each method produces the same results (consistently). Therefore, 
performance measurement of mutual funds is an important thing to do (Huda 2008). Nadifa (2016) showed that the results there are some products mutual funds stock and fixed income mutual fund that has a performance that outperformed for the market. Eva (2010) States that assessment of mutual funds with the method of Sharpe shows 3 mutual funds had a good performance. While 5 other poorly performing mutual funds because portfolio under the market.

\section{METHODS OF RESEARCH}

This research uses descriptive method quantitative because in this study researchers strive to find the performance characteristics of Sharia Equity fund shares were then compared with the market's return. The population in this research is the whole Sharia Equity Fund that are listed in Indonesia in the period 2015 - 2018. Analysis calculation using the Risk-Adjusted Return with Sharpe, Treynor, Jensen-Alpha. Here is example of such model:

$$
S p=(R p-R f) / \sigma p ; T p=(R p-R f) / \beta p ; J A p=R p-[R f+\beta p(R m-R f)]
$$

Where: $S p=$ Sharpe Ratio; $T p=$ Treynor Ratio; $A p=$ Jensen-Alpha Ratio; $R p=$ return portfolio; $\mathrm{Rf}=$ return risk-free interest rate; $\sigma p=$ Standar Deviation; $\beta p=$ Beta Portfolio; $\mathrm{Rm}=$ Return Market.

\section{RESULTS AND DISCUSSION}

Based on the research criteria, there are 21 Sharia equity funds that meet the criteria that are used as research samples. The performance measurement of Sharia equity funds in 2015 - 2018 was carried out using the Sharpe, Treynor, and Jensen-Alpha. The results of the measurements obtained will be compared with market performance, namely the Jakarta Composite Index (JCI) and the Indonesian Sharia Stock Index (ISSI), so that it can determine Islamic stock mutual fund products where outperformed and underperformed from market performance.

The results of the analysis with the Sharpe method. Based on the results of the calculation of the performance of Sharia equity funds in 2015 - 2018 using the Sharpe method, the result is that all Sharia equity funds show negative performance. This shows that all Sharia equity funds based on the Sharpe method are not feasible to be used as investment places and so are the values of the market that show negative performance. However, when compared with its market value, it produces 13 Sharia equity funds that are outperformed against the $\mathrm{JCl}$ market of -2.07414 and ISSI amounting to -2.01012 with the first order, HPAM Syariah Ekuitas -1.45617; Pratama Syariah -1.56893; Pacific Syariah Saham -1.60115; Simas Syariah Featured -1.72111; SAM Sharia Equity Fund -1.75290; OSO Syariah Equity Fund -1.79335; Avrist Equity Amar Syariah -1.92412; Mandiri Investa equity Syariah -1.92499; Sucorinvest Sharia Equity Fund -1.93031; Danareksa Syariah Saham -1.95175; MNC Dana Syariah Equity -1.99648; PNM Ekuitas Syariah -2.00495; Mandiri Investa Atraktif Syariah -2.00690.

The results of the Sharpe method are in accordance with Arief (2017) research which says that there are several equity mutual fund products that have outperformed performance even though the results of the mutual fund value are negative. Measurements using the Sharpe method are rated from each mutual fund product, so the mutual fund product that reaches the third highest position is the first mutual fund, HPAM Syariah Equity, followed by Pratama Syariah and Pacific Syariah Saham in the third rank.

The results of the analysis with the Treynor method. Based on the results of the calculation of the performance of Sharia equity funds in 2015 - 2018 using the Treynor method the results are seen that all Sharia equity funds show negative performance, but there is one positive performance mutual fund, namely OSO Syariah Equity Fund. This means that the OSO Syariah Equity Fund based on the Treynor method is worthy of being used as an investment place in Sharia equity funds. Meanwhile, the performance of the 
market shows a negative performance. When compared with the market value in the calculation model of the Treynor index performance in 2015-2018, it is found that there are 7 Sharia equity funds that are able to outperfomed the $\mathrm{JCl}$ market of -0.57004 and ISSI at 0.60402. Mutual funds that occupy the first rank are the Syariah Equity Fund OSO 1.66342 and then followed by Lautandhana Syariah Shares -0.09685; SAM Sharia Equity Fund 0.15020; PNM Ekuitas Syariah -0.52839; Avrist Equity Amar Syariah -0.53788; Cipta Syariah Equity -0.56225; Manulife Syariah Sektoral -0.56482.

The results of the Treynor method are in accordance with Aida (2015) study which revealed that stock mutual funds have a positive and better performance than Sharpe. The results of the calculation of Sharia equity funds using the Treynor method, are rated from each mutual fund product. If the rank is sorted, the mutual fund products that reach the top three are OSO Syariah Equity Fund, Lautandhana Syariah Shares and SAM Sharia Equity Fund. From the discussion above, the three funds can be an alternative in investing in Islamic stock mutual funds for investors a Sharia equity fund the researchers concluded that the three mutual funds were the best in accordance with the performance that could exceed the market in the period 2015-2019.

The results of the analysis with the Jensen-Alpha method. Based on the results of the calculation of the performance of Sharia equity funds in 2015 - 2018 using the Jensen method, the results of all Sharia equity funds show negative performance. This means that all Sharia equity funds with the Jensen method are not feasible to be used as places of investment and also for the performance of the market which shows negative results. When compared to the market value, the calculation results using the Jensen-Alpha Index performance in 2015-2018 have 18 Sharia equity funds showing better performance than the $\mathrm{JCI}$ and ISSI markets which have values of -0.09814 and -0.09854 . From the outperformed Islamic stock mutual funds, Lautandhana Syariah Shares were ranked first with a value of 0.07511 , followed by SAM Sharia Equity Fund -0.08451; Sucorinvest Sharia Equity Fund 0.09519; Manulife Syariah Sektoral -0.09562; MNC Dana Syariah Equity -0.09567; Batavia Dana Syariah Shares -0.09584; Bahana Equity Syariah -0.09602; Cipta Syariah Equity 0.09605; PNM Syariah Equity -0.09621; Avrist Equity Amar Syariah -0.09627; Mandiri Investa Atraktif Syariah -0.09630; HPAM Syariah Ekuitas -0.09674; Danareksa Syariah Stock -0.09675; Panin Sharia Funds -0.09684; Syariah Mandiri Investa equity -0.09705; Featured Simas Syariah -0.09729; Sharia Trim Stock -0.09732; CIMB Islamic Equity 0.09761 ;

The results of Jensen's method are in accordance with Annisa research (2016) which says the results are stock mutual funds that have outperformed performance better than the $\mathrm{JCl}$ performance. By using the Jensen Index, the calculation of Islamic stock mutual funds is ranked on each mutual fund product. If the ranking is sorted, then the Islamic stock mutual fund products that reach the top three are Lautandhana Syariah Shares which was ranked first and followed by SAM Sharia Equity Fund and Sucorinvest Sharia Equity. From the conclusion of the results above, the three Sharia equity funds can be used as alternative investments and the researchers conclude that the three mutual funds are the best mutual funds in the period 2015-2018 with performance that is able to exceed the market.

\section{MANAGERIAL IMPLICATIONS}

For investors, this research can be used as a reference in investing in Sharia equity funds. It is expected that investors will analyze or determine the performance of a Sharia stock mutual fund before deciding to invest in the equity fund. Because even if managed by a professional Investment Manager, the ability to choose the right mutual fund is still needed. In order to get a high return, investors must choose to invest in Sharia equity fund that have performance above market performance (outperformed).

For investment managers, it is expected that the performance results of Sharia equity funds in this study can be used as material for consideration to further enhance the ability to determine stocks in their investment portfolios in order to improve their mutual fund performance. When selecting stocks to be included in their investment portfolios, investment 
managers should conduct a more in-depth analysis of the performance of the shares in question, not just using a simple strategy or just based on the intuition of the investment manager. This is important enough so that it is better to do the selection of Sharia stocks which are considered the most potential to provide optimal returns in the future by applying various approaches in compiling portfolios to get good performance or returns above market prices, so that later investors can attract investors Islamic stock mutual funds.

\section{CONCLUSION AND SUGGESTIONS}

Conclusions in this study resulted in the results of research on Sharia equity funds with Sharpe, Treynor, and Jensen-Alpha methods in 2015 to 2018 which had negative performance results. Based on the results obtained by Sharia equity funds with the market, the Sharpe index method results in whether 13 outperformed and 8 underperformed. For the index method, the results of Treynor 7 are outperformed and 14 underperformed. The Jensen-Alpha index method can be found in 18 outperformed and 3 underperformed. With the best Sharia equity funds are HPAM Syariah Ekuitas, OSO Syariah Equity Fund, and Lautandhana Saham Syariah.

This research can be used as reading material and knowledge about Sharia equity funds, for further research it is better to add more varied performance calculations with longer time periods.

\section{REFERENCES}

1. Ahmed, Syed Faizan. 2017. Analyzing performance of Islamic and conventional funds. KASBIT business journal vol. 10

2. Ali, Hapzi. 2017. Mutual funds performance: conventional and Sharia product. International journal of economics and financial issues vol 7 no 4.

3. Arifin, Zaenal. 2007. Teori Keuangan \& Pasar Modal. Yogyakarta: EKONISIA.

4. Aziz, Abdul. 2010. Manajemen Investasi Syariah. Bandung: Alfabeta.

5. Huda, Nurul and Mustafa Edwin Nasution. 2008. Investasi Pada Pasar Modal Syariah. Jakarta: KENCANA.

6. Meytasari, Lina. 2013. "Evaluasi Kinerja Reksa Dana Saham Di Indonesia Dengan Metode EROV, Sortino and Sharpe". Jakarta: Universitas Islam Negeri Syarif Hidayatullah Jakarta.

7. Muzdalifa, Eva. 2010. "Analisis Kinerja Reksadana Syariah Pendapatan Tetap and Campuran Dengan Menggunakan Metode Sharpe, Treynor and Jensen". UIN Sunan Kalijaga Yogyakarta.

8. Nadifa, Annisa. 2016. Analisis kinerja reksadana saham dengan menggunakan metode Sharpe, Treynor, Jensen, and information ratio. Journal Management Universitas Islam Indonesia.

9. Pujiarti, Trisiwi. 2015. Analisis kinerja reksadana saham dengan menggunakan metode Sharpe and Jensen. Jurnal ekonomi and manajemen IPB vol 2 no 2

10. Rahmah, 2016. Analisis perbandingan kinerja reksadana syariah and kinerja reksadana konvensional dengan metode Sharpe, Treynor, and Jensen. J. Analytica Islamica, 5(1).

11. S, Burhanuddin. 2010. Aspek Hukum Lembaga Keuangan Syariah. Graha IImu.

12. Suhartono., \& Fadlillah Qudsi. 2009. Portofolio and Bursa Efek: Pendekatan Teori and Praktik. Yogyakarta: UPP STIM YKPN.

13. Sunarsih, Uun. 2015. Analysis of the Performance of Islamic Mutual Funds in Indonesia by using Sharpe, Treynor and Jensen. Research Journal of Finance and Accounting, 6.

14. Tsay, Ruey S. 2005. Analysis of financial time series. USA: Wiley.

15. Yulianto, Arief. 2017. Analisis kinerja reksadana saham dengan metode Sharpe, Treynor, and Jensen. Management Analysis journal, 6(1).

16. Yuzi, Aida. 2015. Performance Evaluation Of Islamic Mutual Funds In Malaysia Based On Asset Portfolio. International Conference on Statistics in Science, Business and Engineering. 